\title{
Pendampingan Pembelajaran IPA Bagi Peserta Didik SDN 38 Ampenan Untuk Materi Bunyi, Cahaya, Listrik dan Magnet
}

\author{
Jannatin 'Ardhuha ${ }^{1 *}$, Lalu Rudyat Telly Savalas $^{2}$, Nurwahidah ${ }^{3}$ \\ ${ }^{\text {I}}$ Program Studi Pendidikan Fisika, FKIP Universitas Mataram, Mataram, Indonesia. \\ ${ }^{2}$ Program Studi Pendidikan Kimia, FKIP Universitas Mataram, Mataram, Indonesia. \\ ${ }^{3}$ Program Studi Pendidikan Guru Sekolah Dasar, FKIP Universitas Mataram, Mataram, Indonesia.
}

DOI: https://doi.org/10.29303/jpmsi.v2i2.43

Citation: 'Ardhuha, J., Savalas, L. R. T., Nurwahidah. 2020. Pendampingan Pembelajaran IPA Bagi Peserta Didik SDN 38 Ampenan Untuk Materi Bunyi, Cahaya, Listrik dan Magnet. Jurnal Pengabdian Masyarakat Sains Indonesia (JPMSI). 2(2): 102-107.

\section{Article history}

Received: June $16^{\text {th }} 2020$

Revised: June $24^{\text {th }} 2020$

Accepted: June $26^{\text {th }} 2020$

*Corresponding Author: Jannatin

'Ardhuha, FKIP Universitas

Mataram, Mataram, Indonesia.

Email: j.ardhuha@unram.ac.id

\section{Pendahuluan}

Ilmu Pengetahuan Alam (IPA) merupakan salah satu pelajaran penting bagi peserta didik di tingkat sekolah dasar (SD). IPA merupakan cara mencari tahu tentang alam secara sistematis untuk menguasai pengetahuan, fakta-fakta, konsep, prinsip, proses penemuan dan sikap ilmiah (Depdiknas, 2006). Hakekat dari pembelajaran IPA ini adalah mengembangkan pemahaman peserta didik tentang alam, mengembangkan keterampilan yang diperlukan untuk memperoleh atau mengembangkan pengetahuan yang baru, dan mengembangkan sikap positif pada peserta didik, (Syahrial dkk, 2020).

Keterampilan proses sains dan sikap ilmiah merupakan keterampilan dan sikap yang dapat dikembangkan dalam diri peserta didik selama proses pembelajaran IPA. Keterampilan ini dapat berupa keterampilan melakukan observasi, merumuskan hipotesis, merencanakan dan

\begin{abstract}
Abstrak: Telah dilakukan kegiatan pendampingan bagi peserta didik kelas VI di SD Negeri 38 Ampenan pada pelajaran IPA, meliputi pemantapan konsep dengan mengulas kembali konsep dasar materi bunyi, cahaya, listrik dan

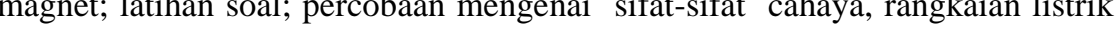
menambah wawasan dan membantu peserta didik untuk mengkonfirmasi jawaban mereka dalam latihan soal, apakah sesuai dengan hasil percobaan, sehingga pelajaran IPA tidak lagi terfokus pada segala sesuatu yang harus dihapal. Berdasarkan hasil angket yang diberikan kepada peserta didik di akhir segatan ini, dapat teridentifikasi rasa ingin tahu, rasa ingin mencoba dan rasa kegiatan ini berlangsung, sehingga besar harapan peserta didik agar kegiatan seperti ini dapat dilanjutkan.
\end{abstract}

Kata kunci: IPA, bunyi, cahaya, listrik, magnet, percobaan, demonstrasi.

melaksanakan penelitian (eksperimen), mengendalikan variabel, menginterpretasi atau menafsirkan data, menyusun kesimpulan sementara/interferensi, memprediksi, menerapkan dan mengkomunikasikan, (Sri Sulistyorini, 2007). Sedangkan sikap ilmiah dapat meliputi sikap ingin tahu, sikap objektif terhadap data atau fakta, sikap berpikir kritis, sikap penemuan dan kreativitas, sikap berpikir terbuka dan bekerja sama, sikap ketekunan, sikap peka terhadap lingkungan, optimis, pemberani dan kreatif, (Siti Fatonah dan Zuhdan K. Prasetyo, 2014; Maskoeri Jasin, 2010).

Peranan guru, peserta didik, dan interaksi keduanya dengan sumbur belajar memiliki andil yang besar bagi keberhasilan proses pembelajaran IPA. Di sini guru tidak hanya dituntut untuk menguasai materi saja, akan tetapi guru harus menguasai berbagai metode mengajar yang tepat dan terampil dalam memilih, menentukan dan menggunakan media atau alat peraga dalam pembelajaran, (Elmi Hastuti, 2019). Peran aktif dari 
'Ardhuha et al, Jurnal Pengabdian Masyarakat Sains Indonesia 2020, 2 (2): 102-107. DOI : https://doi.org/10.29303/ipmsi.v2i2.43

peserta didik (student centered) sangat diharapkan dalam proses tersebut.

Di sekolah sering dijumpai banyak peserta didik merasa pembelajaran IPA merupakan pelajaran yang sulit dipahami dan tidak menyenangkan. Hal ini dapat disebabkan karena materi IPA yang diajarkan terlalu padat dan banyak mengandung hapalan, terbatasnya media pembelajaran yang dipergunakan oleh guru untuk menjelaskan materi, kurangnya kemampuan guru untuk menghubungkan materi pembelajaran dengan penerapan materi tersebut dalam kehidupan seharihari, guru cenderung mendominasi pembelajaran, dan materi yang terpaku pada ketercapaian target menyebabkan peserta didik kurang memiliki kesempatan untuk menggali kemampuan dirinya, (Abdul Khoir HS., 2008; Imanuel S. A., 2015; Irani Ramadhani, 2012).

Menurut Usman Samatowa (2006), ketika memberdayakan peserta didik dalam pembelajaran IPA, guru perlu memperhatikan 4 aspek yaitu penting untuk memahami pada saat memulai kegiatan pembelajaran, peserta didik telah mempunyai berbagai konsepsi dan pengetahuan tentang materi yang pernah mereka pelajari; hal yang utama dalam pembelajaran IPA adalah aktivitas peserta didik melalui berbagai kegiatan nyata dengan alam; kegiatan bertanya merupakan bagian yang paling utama dalam pembelajaran IPA; dan sebaiknya diberikan kesempatan kepada peserta didik untuk mengembangkan kemampuan berpikirnya dalam menjelaskan suatu masalah. Untuk menunjang hal tersebut perlu dilakukan serangkaian kegiatan menggunakan media pembelajaran yang dapat diintegrasikan dalam berbagai metode pembelajaran seperti kegiatan demonstrasi, diskusi, simulasi, observasi, percobaan dan proyek.

Berdasarkan 4 aspek tersebut, pendekatan keterampilan proses dapat dipilih oleh guru untuk diterapkan pada pembelajaran IPA di sekolah. Suryosubroto (2002) menyatakan ada dua kegiatan utama yang harus dilalui pada pendekatan ini yaitu pemanasan dan proses belajar. Kegiatan pemanasan bertujuan untuk mengarahkan peserta didik pada pokok permasalahan agar mereka siap secara mental, emosional dan fisik. Kegiatannya dapat berupa pengulasan langsung pengalaman yang pernah dialami peserta didik maupun guru, pengulasan bahan pengajaran yang pernah dipelajari pada waktu sebelumnya, kegiatankegiatan yang menggugah dan mengarahkan
e-ISSN : $2715-2537$

p-ISSN : 2715-2545

perhatian peserta antara lain meminta pendapat/saran peserta didik, menunjukkan gambar, slide, film, dan benda lain. Kegiatan kedua dititikberatkan pada proses belajar, di mana setiap kegiatan hendaknya selalu mengikutsertakan secara aktif peserta didik guna mengembangkan keterampilan-keterampilan proses sains.

SD Negeri 38 Ampenan adalah salah satu sekolah di kota Mataram yang telah menerapkan kurikulum 2013 (K-13) untuk seluruh kelas (kelas I sampai dengan kelas VI) pada awal tahun pelajaran 2019/2020. Pendekatan saintifik telah diupayakan untuk diterapkan di pembelajaran IPA untuk peserta didik kelas 4, 5 dan 6 (kelas tinggi) sekolah ini. Akan tetapi tidak semua materi dapat disampaikan oleh guru dengan pendekatan ini. Hal ini dikarenakan adanya keterbatasan waktu dan tenaga untuk menyiapkan alat dan bahan yang dipergunakan, serta memerlukan kreativitas dan ketekunan guru dalam menyusun panduan percobaan dan rangkaian alat yang benar. Sehingga penyampaian materi IPA lebih banyak menggunakan metode ceramah dan diselingi dengan pemberian tugas.

Peserta didik perlu mendapatkan kesempatan dan pengalaman peserta didik untuk berinteraksi dengan sumber belajar, baik berupa buku bacaan, media dan alat pembelajaran, melakukan percobaan, menganalisis suatu masalah, menarik kesimpulan, bekerja sama dan saling menghargai pendapat orang lain, dan kemampuan lainnya. Keterampilan proses sains dan sikap ilmiah ini perlu ditanamkan, dilatih dan dikembangkan untuk kelanjutan mereka menghadapi pembelajaran IPA di tingkat sekolah yang lebih tinggi. Oleh karena itu, perlu dilakukan kegiatan pendampingan pembelajaran IPA bagi peserta didik kelas VI berupa pemantapan konsep IPA melalui pengulasan materi, latihan soal, dan penyajian video pembelajaran. Materi IPA yang dibahas pada kegiatan ini berupa materi pada lingkup energi dan perubahannya meliputi materi bunyi, cahaya, listrik dan magnet untuk kelas tinggi.

Dari keempat materi tersebut terdapat beberapa konsep yang dirasa terlalu abstrak (sulit dibayangkan) bagi peserta didik, sehingga percobaan dan demonstasi perlu dilakukan dalam kegiatan ini. Percobaan bertujuan untuk memberi kesempatan pada peserta didik untuk mengalami dan membuktikan sendiri suatu konsep yang telah disampaikan oleh guru, (Jannatin dkk, 2013; Sarjono dkk, 2018). Sedangkan kegiatan 
'Ardhuha et al, Jurnal Pengabdian Masyarakat Sains Indonesia 2020, 2 (2): 102-107. DOI : https://doi.org/10.29303/ipmsi.v2i2.43

demonstrasi merupakan salah satu kegiatan yang menyenangkan bagi peserta didik dan guru, di mana kegiatan ini bertujuan untuk membantu memusatkan perhatian peserta didik pada perilaku sains dalam rangka meningkatkan pengetahuan mereka, (Yunita dkk, 2018).

\section{Metode}

Pelaksanaan kegiatan secara umum terbagi atas 3 tahapan yaitu persiapan, pelaksanaan, dan umpan balik. Tahap persiapan meliputi observasi
e-ISSN : 2715-2537

p-ISSN : 2715-2545

tempat kegiatan pengabdian, pengumpulan informasi mengenai calon peserta kegiatan, koordinasi dengan guru mata pelajaran IPA di sekolah yang dituju, pengumpulan soal USBN, pemilihan materi pelajaran IPA, penyiapan media pembelajaran untuk demonstrasi dan percobaan, dan penyusunan materi dalam powerpoint. Pengabdian ditujukan untuk peserta didik kelas VI di SDN 38 Ampenan yang berjumlah 51 orang. Materi IPA yang dipilih dalam kegiatan ini adalah materi bunyi, cahaya, listrik dan magnet. Soal yang digunakan merupakan kumpulan soal-soal USBN SD dari tahun 2016 sampai 2019. Kegiatan persiapan pengabdian ditunjukkan pada Gambar 1.
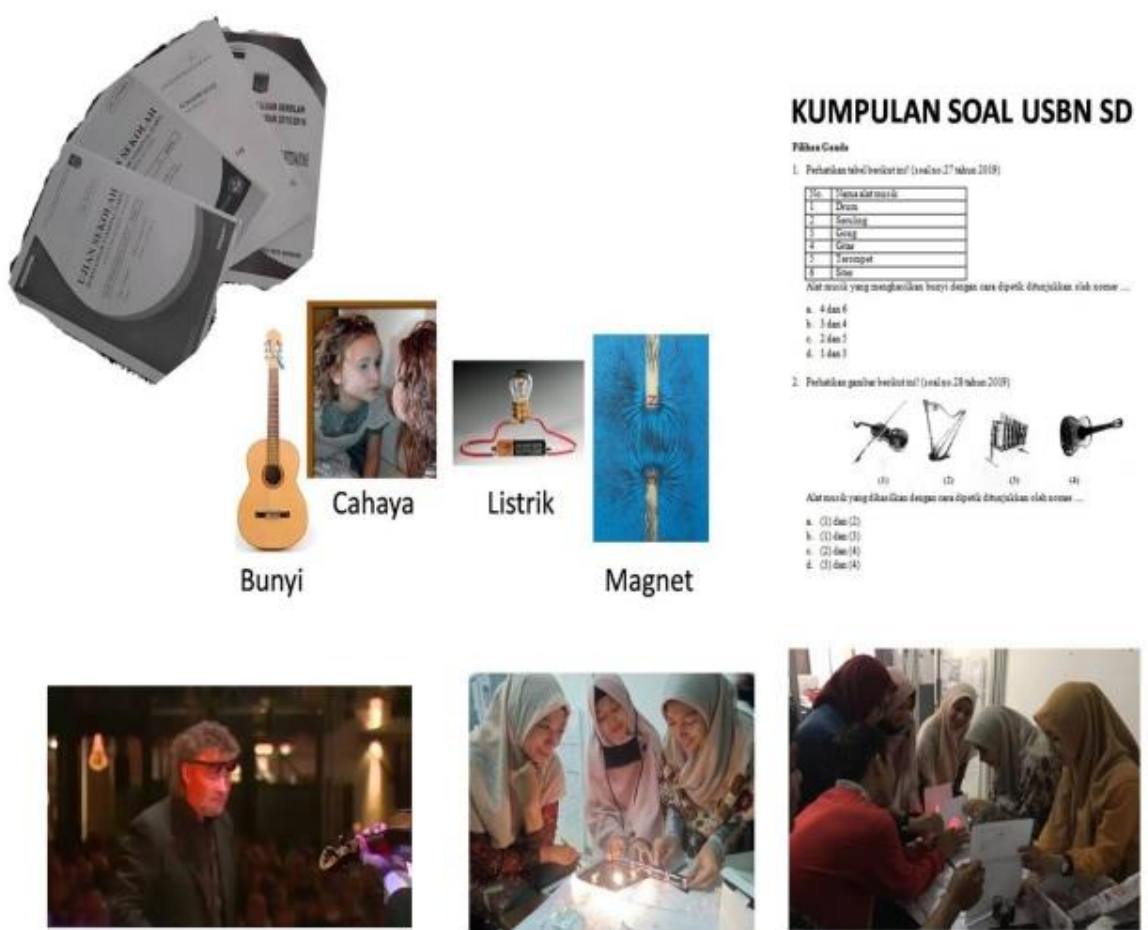

Gambar 1. Kegiatan persiapan terdiri dari pengumpulan soal USBN dan penyiapan media pembelajaran.

Tahap pelaksanaan meliputi kegiatan tes awal berupa latihan soal, analisis jawaban peserta didik, pemaparan materi, pembahasan latihan soal, percobaan dan demonstrasi. Latihan soal terdiri dari 21 soal pilihan ganda dan 2 soal essai. Kegiatan ditutup dengan umpan balik yang berupa pengisian angket respon peserta didik terhadap kegiatan pengabdian yang dilakukan. Angket respon peserta didik terdiri dari 3 pertanyaan terbuka, mengenai alasan mereka menyukai pelajaran IPA, materi IPA dalam kegiatan pengabdian ini yang mereka mengerti dan tidak dimengerti, dan adakah keinginan peserta didik agar kegiatan pengabdian seperti ini dapat dilakukan kembali di sekolah mereka.

\section{Hasil dan Pembahasan}

Kegiatan pertama yang dilakukan adalah peserta didik mengerjakan latihan soal materi cahaya, bunyi, listrik dan magnet. Analisis penguasaan konsep dan kesulitan peserta didik berdasarkan hasil jawaban peserta didik dalam mengerjakan soal dalam bentuk pilihan ganda dipaparkan sebagai berikut:

1. Materi Bunyi 
'Ardhuha et al, Jurnal Pengabdian Masyarakat Sains Indonesia 2020, 2 (2): 102-107. DOI : https://doi.org/10.29303/ipmsi.v2i2.43

- Sebagian besar peserta didik mampu mengidentifikasi alat musik yang menghasilkan bunyi dengan cara dipetik dan digesek. Namum beberapa peserta didik kesulitan ketika diberikan daftar alat musik yang tidak biasa mereka lihat dan dengar seperti siter, harpa, kecapi, ukelele, harmonika dan saksofon.

- 24 dari 51 peserta didik salah menjawab bagian dari alat musik gitar yang menjadi sumber bunyi ketika gitar tersebut dimainkan.

- Lebih dari setengah peserta didik mampu mengklasifikasikan benda-benda yang dapat menyerap bunyi.

2. Materi Cahaya

- Peserta didik dapat menjawab posisi bayangan benda berdasarkan posisi sumber cahaya. Akan tetapi bila redaksi soal hanya memberikan nomer $(1,2,3)$ dan huruf $(\mathrm{P}$, $\mathrm{Q}, \mathrm{R})$ sebagai simbol untuk sumber cahaya dan letak bayangan, peserta didik mengalami kesulitan dalam menjawabnya.

- Peserta didik kesulitan dalam menganalisa soal mengenai penggunaan cermin oleh penjaga toko-toko swalayan untuk mengamati keadaan. Sebagian besar peserta didik menjawab cermin datar. Hal ini mungkin disebabkan karena guru (pendidik) lebih sering menerangkan penggunaan cermin cembung di spion kendaraan dan di tikungan jalan.

- Sebagian besar peserta didik (44 orang) mampu menyimpulkan sifat cahaya yang dapat dipantulkan dari suatu peristiwa sehari-hari.

3. Materi Listrik

- Rangkaian listrik merupakan materi yang dipelajari peserta didik di kelas VI. Ketika tes ini diberikan kemungkinan peserta didik belum mendapat penjelasan mengenai materi ini di kelas. Sehingga kurang dari setengah peserta didik yang mampu menjawab soal-soal mengenai rangkaian listrik ini dengan benar.

- Setengah peserta didik (25 orang) mampu mengidentifikasi benda yang memiliki sifat konduktor.

4. Materi Magnet

- Sebagian peserta didik mampu mengidentifikasi dan mendefinisikan cara
e-ISSN : 2715-2537

p-ISSN : 2715-2545

membuat magnet dengan metode gosokan dan elektromagnetik berdasarkan gambar yang ditampilkan dalam soal. Akan tetapi peserta didik kesulitan dalam mengidentifikasi cara membuat magnet dengan metode induksi.

Untuk soal essai mengenai rangkaian listrik, sebagian besar peserta didik mampu menjelaskan perbedaan penggunaan lampu rangkaian seri dan paralel berdasarkan keadaan lampu dan baterai penyusunnya. Begitu pula dengan kemampuan peserta didik dalam menalar dan menganalisa alasan kilat cahaya lebih dahulu dilihat dibandingkan suara petir yang meraka dengar. Peserta didik sudah mampu menghubungkan konsep perambatan cahaya lebih besar dibandingkan dengan perambatan bunyi berdasarkan fenomena yang mereka sering jumpai dalam kehidupan sehari-hari.

Berdasarkan uraian di atas menunjukkan bahwa tidak semua peserta didik mampu menjawab soal-soal yang diberikan. Hal ini mengindikasikan perlunya pemantapan konsep dari keempat materi tersebut. Pemantapan konsep dari materi-materi ini perlu ditingkatkan baik dengan mengulas kembali konsep dasarnya.

Kegiatan selanjutnya yang dilakukan adalah pemaparan materi yang ditampilkan dalam bantuan powerpoint. Materi bunyi yang dipaparkan adalah definisi bunyi, frekuensi bunyi, sumber bunyi, alat musik, sifat-sifat bunyi, gema dan gaung. Jika dari tahapan sebelumnya diketahui peserta didik mengalami kesulitan mengenai alat musik dan cara alat tersebut menghasilkan bunyi, maka pada tahapan ini ditampilkan video singkat mengenai hal tersebut. Di samping itu, ditambahkan pula sebuah video penampilan orchestra musik, peserta didik diminta untuk mengidentifikasi dan menyebutkan 10 alat musik yang ada di video tersebut.

Latihan soal materi bunyi yang diberikan pada tahap pertama diulas kembali pada tahapan ketiga ini. Peserta didik diberi kesempatan untuk mengutarakan jawaban mereka tentang soal-soal tersebut. Didasarkan pada pengetahuan awal dan penekanan konsep pada tahapan pemaparan materi, peserta didik dapat menjawab seluruh pertanyaan dengan benar.

Untuk materi cahaya dan listrik, setelah tahapan pemaparan materi, peserta didik diajak untuk mengkonfirmasi jawaban latihan soal 
'Ardhuha et al, Jurnal Pengabdian Masyarakat Sains Indonesia 2020, 2 (2): 102-107. DOI : https://doi.org/10.29303/ipmsi.v2i2.43

mereka melalui serangkaian percobaan. Percobaan yang dilakukan berupa percobaan cahaya dapat merambat lurus, cahaya dapat melalui benda bening, cahaya dapat dipantulkan dan dibiaskan, rangkaian listrik terbuka dan tertutup, serta rangkaian listrik seri, paralel dan campuran. Gambar 2 menunjukkan peserta didik tertarik dan bersemangat dalam melakukan percobaan untuk membuktikan sifat cahaya dapat merambar lurus.

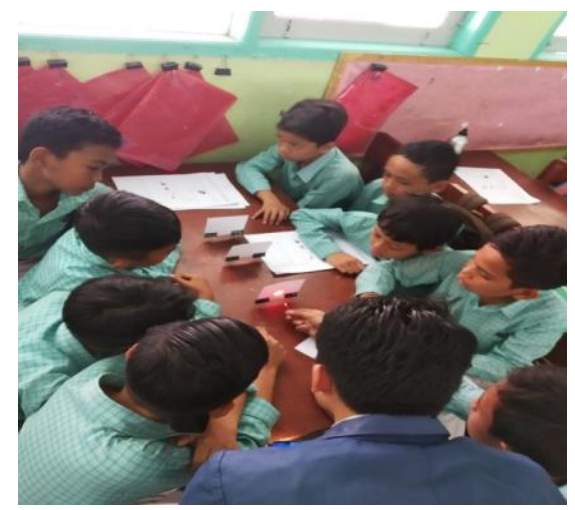

Gambar 2. Peserta didik melakukan percobaan yang membuktikan sifat cahaya.

Demonstasi pembuatan magnet melalui cara digosok, diinduksi dan elektoktromagnetik merupakan rangkaian kegiatan dalam pengabdian ini yang dipilih untuk menjelaskan materi magnet. Kegiatan ini bertujuan untuk membantu peserta didik mempelajari cara membuat magnet untuk meningkatkan pengetahuan dan keyakinan mereka akan konsep ini. Sehingga pelajaran IPA tidak hanya kegiatan yang sebatas hapalan, akan tetapi dapat diperoleh dari pengalaman dan pengamatan langsung. Antusias peserta didik pada saat kegiatan demonstasi membuat magnet dengan metode elektromagnetik, terlihat beberapa peserta didik dalam posisi berdiri sebagai upaya melihat dengan jelas proses pembuatan magnet tersebut, seperti ditunjukkan pada Gambar 3 berikut ini.

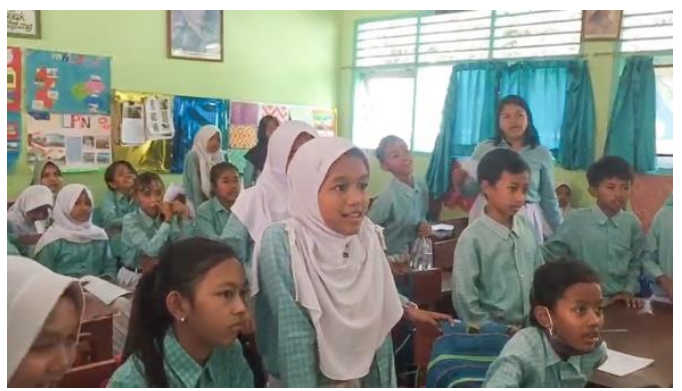

Gambar 3. Ekspresi peserta didik menyaksikan demonstrasi cara membuat magnet.
e-ISSN : $2715-2537$

p-ISSN : 2715-2545

Di akhir kegiatan, peserta didik diminta mengisi angket respon mereka terhadap pelaksanaan kegiatan pengabdian ini. Berdasarkan angket tersebut diketahui bahwa sebagian besar peserta didik menyukai pelajaran IPA jika materi yang disampaikan mudah (gampang) untuk dipahami, seperti materi mengenai tumbuhan, alam, ekosistem, tulang hewan, manusia, maupun materi yang disampaikan dalam kegiatan ini.

Jawaban peserta didik beragam ketika mereka ditanya mengenai materi apa yang dapat dimengerti dan tidak dimengerti. Ada yang dapat mengerti seluruh materi yang disampaikan, ada yang sebagian, dan ada yang hanya tentang bunyi saja. Peserta didik juga masih kesulitan dalam memahami rangkian listrik seri, paralel dan campuran. Hal ini mungkin dikarenakan alokasi waktu yang kurang untuk melakukan percobaan, sehingga tidak semua peserta didik dapat memahami konsep listrik tersebut.

Peserta didik sangat ingin kegiatan seperti ini dilakukan kembali di sekolah mereka, dengan alasan karena penjelasan yang diberikan mudah, seru dan menyenangkan, mereka suka, dapat menambah ilmu pengetahuan dan membuat mereka pintar, mereka ingin kegiatan seperti ini dilakukan setiap bulan, mereka dapat melakukan praktik (percobaan), mereke senang melakukan eksperimen, dan mereka merasa dengan cara seperti ini peserta didik dapat belajar dengan baik.

\section{Kesimpulan}

Kegiatan pengabdian ini sangat bermanfaat karena menambah wawasan dan dapat mengevaluasi kemampuan peserta didik dalam menjawab soal-soal. Demonstrasi dan percobaan dapat membantu peserta didik dalam memahami konsep IPA tentang cahaya, bunyi, listrik dan magnet. IPA tidak lagi terfokus pada sesuatu yang harus dihapal. Rasa ingin tahu, rasa ingin mencoba, dan rasa senang peserta didik untuk belajar IPA tumbuh dan berkembang selama kegiatan ini berlangsung.

\section{Saran}

Alokasi waktu dan perencanaan kegiatan yang matang menjadi kunci utama dari keberhasilan kegiatan ini. Guru dapat menggunaan metode percobaan dan demonstrasi untuk menunjang kegiatan pembelajaran IPA di kelas. 
'Ardhuha et al, Jurnal Pengabdian Masyarakat Sains Indonesia 2020, 2 (2): 102-107. DOI : https://doi.org/10.29303/ipmsi.v2i2.43

Kegiatan seperti ini perlu terus dilakukan dan dapat dilanjutkan ke sekolah lainnya untuk meningkatkan motivasi belajar peserta dan penguasaan konsep IPA.

\section{Ucapan Terima Kasih}

Tim pengabdian mengucapkan terima kasih kepada pihak sekolah SDN 38 Ampenan yang telah memfasilitasi terlaksananya kegiatan ini, dan juga kepada Mega Safana, Nurjamila, Mulya Rahmawati, Romi Setiawan, Malahayati Rahayu Sulastri, dan Muhammad Ari Kusumawadi yang telah mendukung pelaksanaan kegiatan ini.

\section{Daftar Pustaka}

Abdul Khoir HS. 2008. Kesulitan Belajar Sains: Studi Pada Pelaksanaan Pembelajaran Mata Pelajaran Sains Kelas IV Sekolah Dasar Negeri 10 Jatimulya Kabupaten Bekasi. Turats. 4.

Depdiknas. 2006. Model Kurikulum Tingkat Satuan Pendidikan. Jakarta: Badan Standar Nasional Pendidikan, Departemen Pendidikan Nasional.

Elmi Hastuti. 2019. Upaya Meningkatkan Hasil Belajar IPA dengan Menggunakan Medai Tiga Dimensi Pada Siswa Kelas IV. Jurnal Imiah Pendidikan Guru Sekolah Dasar. Vol.12 No.1, 2019.

Imanuel Sairo Awang. 2015. Kesulitan Belajar IPA Peserta Didik Sekolah Dasar. Vox Edukasi Vol. 6 No.2, November 2015.

Irani Ramadhani S. 2012. Keefektifan Penggunaan Teknik Mind Map Pada Pembelajaran Keterampilan Berbicara Bahasa Jerman Peserta Didik Kelas XI SMA Negeri 1 Imogiri Bantul. S1 Thesis, Universitas Negeri Yogyakarta.

Jannatin dkk. 2013. Pengembangan Panduan Praktikum Fundamental Of Physics Untuk Meningkatkan Kualitas Pelaksanaan Praktikum Pada Program Khusus PGMIPABI di FKIP Unram. Prosiding Seminar Nasional "Arahan Pendidikan MIPA Masa Depan; Antara Harapan dan Kenyataan". FKIP Univeristas Mataram.

Maskoeri Jasin. 2010. Ilmu Alamiah Dasar. Jakarta: PT Raja Grafindo Persada.
e-ISSN : 2715-2537

p-ISSN : 2715-2545

Sarjono dkk, 2018. Development of Physics Lab Assesment Instrument for Senior High School Level. International Journal of Instruction, Vol.11. No.4.

Siti Fatonah dan Zuhdan K. Prasetya. 2014. Pembelajaran Sains. Yogyakarta: Ombak.

Sri Sulistyorini. 2007. Model Pembelajaran IPA Sekolah Dasar dan Penerapannya dalam KTSP. Yogyakarta: Tiara Wacana.

Suryosubroto B. 2002. Proses Belajar Mengajar Di Sekolah. Jakarta: PT Rineka Cipta.

Syahrial A., dkk. 2020. Bimbingan Penggunaan Kit Fluida Alternatif yang Berasal dari Sampah Anorganik Bagi Siswa SD Negeri 6 Mataram. Jurnal Pengabdian Masyarakat Sains Indonesia, Vol. 2 No.1, Juni 2020.

Usman Samatowa. 2010. Pembelajaran IPA di Sekolah Dasar. Jakarta Barat: PT Indeks Permata Puri Media.

Yunita dkk. 2018. Demonstrasi Menggunakan Bahan Sederhana Untuk Mengenalkan Reaksi Kimia Pada Siswa Sekolah Dasar. Jurnal Pendidikan dan Pengabdian Masyarakat. Vol.1 No.2, Agustus 2018. 